\title{
The Empire and the Nation in the 20th Century
}

Models of Coexistence

\author{
Alexander A. Vershinin
}

\begin{abstract}
Alexander A. Vershinin, PhD in History
Lomonosov Moscow State University, Russia

Department of the History of Russia of the 20th-21st Centuries

Senior Lecturer

ORCID: 0000-0001-5206-8013

Researcher ID Q-5433-2017

E-mail: averchinine@gmail.com

Address: 27, Bldg. 4, Lomonosovsky Prospect, Moscow 119192, Russia

This project was implemented with support from the research school "Transformations of Culture, Society and History: A Philosophical and Theoretical Reflection," Moscow State University.
\end{abstract}

DOI: $10.31278 / 1810-6374-2020-18-2-108-131$

\section{ABSTRACT}

This article studies the development of empires in the 20th century and ways of their interaction with nation-states. That century began as an age of empires. The elites of the world's leading countries were certain that only empires possessing the resources of entire continents had the prospects of full-fledged development. World War I ruined the continental empires and discredited the very notion of imperialism, but it by no means devalued the empire as a form of political organization. The 20th century saw several attempts to recreate the empire in modern conditions and reconcile it with the political demands of nationalism. The Soviet model relied on the politicization of ethnicities in order to reduce the destructive potential of nationalism and keep the imperial entity integral. While boasting certain advantages, the Soviet model collapsed, failing to adjust itself to the conditions of modern development. Its antipode was born in the Third 
Reich. The European Union's "soft empire" project emerged largely as an alternative to Germany's "hard imperialness." The United States turned out to be the most viable empire of the 20th century. The main conclusion of this article is that contemporary history is marked by the emergence of state structures of the imperial type. Their interaction is likely to determine international relations in the 21st century.

Keywords: empire, imperialism, nationalism, the USSR, the Third Reich, the EU, the U.S.

T $\mathrm{n}$ his quest to explore the "long nineteenth century," British historian Eric Hobsbawm coined a special term for it: the 'era of empires' (Hobsbawm, 1987). He did so for good reason. By the beginning of World War I, a significant part of the political map of the world was painted imperial colors. The three largest empires-British, Russian, and French-together occupied more than half of the land mass. (Before 1914 the notion of empire had no negative connotation. On the contrary, empire and imperialness were associated with civilization, prosperity and progress. "For the core, imperial people, empire was seen as a source of glory, status, and a meaningful role in mankind's history" (Lieven, 2002). Political and intellectual elites were certain that only empires, with the resources of entire continents at their disposal, had prospects for full-fledged development amid the intensifying struggle for a "place in the sun." It is the empire that had the civilizing mission, making the achievements of modern culture available in the remote corners of the world.

Rising nationalism was unable to shake loose the belief that empires were destined to have a glittering future. In many ways, it imposed new approaches to building empires and keeping them in good shape. The ruling circles were forced to devise new ways of retaining the reins of power. More often than not they were successful. Nationalism per se was not an imminent threat to the empire, which historically was a flexible political system. The point at issue was how successful the elites would be in their attempts to "tame" nationalism, that is, whether the 
imperial power structure would be effective enough. It would hardly be appropriate to state that a certain antagonism between the empire and the nation-state was predetermined at the beginning of the 20th century (Miller, 2016, p. 109-110). On the contrary, newly built nationstates sought to gain an imperial status, and not only on paper, but also in real life, while empires began to build their own national core.

At the same time, the intellectuals grew increasingly aware that new imperialism was a phenomenon unparalleled in the past and tightly linked with the current trends. Vladimir Lenin in his work Imperialism as the Highest Stage of Capitalism scrutinized it through the lens of economics. He maintained that economic competition was the driving force of imperialist expansion (Lenin, 1969b, p.299-426). English scholar John Hobson (1902) argued that economic imperialism was only one facet of a larger process. It was based on a philosophy that in many respects differed from the one the architects of ancient and medieval empires proceeded from.

Empire is inseparable from the idea of expansion. The latter is probably crucial to its understanding. Michael Mann identifies four sources for such expansion: military, political, economic, and ideological (Mann, 1986, p.518-524). Dominic Lieven adds another two: demographic and geographical (Lieven, 2002). All empires, starting with the ancient ones, used these expansion tools (Eisenstadt, 1963). However, classical and medieval empires, as Hobson notes, had an important distinction from the new great powers. The Roman Empire, in many ways a model polity of this type, was an international entity. "The root idea of empire in the ancient and medieval world was that of a federation of States under a hegemony, covering in general terms the entire known or recognized world, such as was held by Rome under the so-called pax Romana" (Hobson, 1902, p.6). "The new imperialism," he wrote, "differs from the older, first, in substituting for the ambition of a single growing empire the theory and the practice of competing empires motivated by similar lusts of political aggrandizement and commercial gain" (Hobson, 1902, p.324).

Universalism, the idea of the unity of the human race, gave way to competition among large political associations that aspired to dominate 
the globe. That struggle embraced all spheres of public life. Researchers point to one important feature of traditional empires: they neglected direct control of the life of their subjects for the sake of territorial expansion (Strayer, 1970, p. 11). As P. Bourdieu notes, these polities "never included the people, or did so only to a small extent, in political processes or economic activities that went beyond the immediate local interests" (Bourdieu, 2012, p.297). The empires of the modern era relied on achievements in science and engineering and grew strong enough to mobilize all of society's resources to carry out expansion. A direct armed conflict between them could not but turn global.

World War I is rightly called the suicide of Europe. It would be even more appropriate to consider it the suicide of empires. WWI graphically demonstrated that the major threat to any empire was not domestic nationalism, but another empire. Empires got engaged in mortal combat and collapsed almost simultaneously. The survivors, bled white, had to take a break to ponder over their own future. "Modern global imperialism," notes A. Tooze, "was a new radical force, and not a relic of the old world. The same feature made the problem of establishing world domination 'after imperialism' unprecedented" (Tooze, 2019b, p.42).

An important aspect of this global challenge was the fate of the ravaged political space that the extinct European empires left behind. Their constituent peoples, who gained sovereignty overnight, had lost their statehood far back in the past or never had one. In the 20th century it had to be recreated or built from scratch on a new basis. The juvenile elites of the newly founded countries opted for the nation-state as a model to follow. Those were mostly half-baked projects, sketchy and not very efficient. The examples of successful ones in the interwar years are few. Eastern Europe entered a period of lasting instability, with internal interethnic and external interstate contradictions growing far and wide.

The colonial powers of the Old World survived World War I and emerged victorious from it. However, they had to rethink the relationship between the imperial idea and national identity. Military overstrain put the overseas territories of Great Britain and France to a serious test. The French and British nations had been formed as 
the centers of colonial empires. This process went alongside empirebuilding efforts and was in many ways linked with it (Weber, 1976; Colley, 1992). The tendency towards the emancipation of the colonies, which clearly manifested itself after 1918, brought to the forefront the question of preserving the integrity of the national core. None of the elites had a clear answer at hand. Deep socio-political and economic rifts inside Western societies added to this confusion.

The problem, therefore, was in devising a new political model the nations could follow. Imperialism, which arose at the end of the 19th century, proved fraught with disastrous consequences that discredited the concept of the empire in many respects. This was evidenced by the 1919 Paris Peace Conference and the very structure of post-war settlement (D'Agostino, 2012, pp.112-143). The empires, their military blocs, and their imperial expansionist policies were to be discarded once and for all. But were there any alternatives? Some existed only in the minds of the political and intellectual elites as sets of abstract ideas, yet to be translated into life. Such experiments often ended in failure, so new ideas of empire-building would surface again and again (Tooze, 2019).

But what should a reincarnated empire look like? Where could it rely on the legacy of the 19th-century empires, and where should it go by the new realities brought about by a century of masses and ideologies? What model of relations between the core and the periphery, the imperial core and the nations could suit the new realities best? Naturally, this challenge was perceived differently in different parts of the world. A great deal depended on the local specifics and history. Whatever the case, the empire turned out to be at least one of the prototypes of new models of statehood. Let us review some of them.

\section{THE SOVIET EMPIRE}

The Bolsheviks' project was probably the most ambitious one. From the very outset they were going to build something more than a state. Their ideology rejected statehood as a form of political organization of society. It was believed that the Soviet system that emerged after the seizure of power by the working class, once finalized as expected, would make unnecessary both the state and all of its attributes: the 
machinery of violence, bureaucracy, the legal system, foreign policy, etc. All social strata, including ethnic communities, would be dissolved in it. This project, which Vladimir Lenin described in his work The State and the Revolution (Lenin, 1969a, pp.1-50), was formulated as universal. It is noteworthy that the first Soviet Constitution of 1918 interpreted citizenship as membership of a political nation in an intentionally broad sense. The principle of "solidarity of workers of all nations" implied that the rights of a Soviet citizen were granted to all foreigners who belong to the working class or the working classfriendly peasantry. So, the model of legitimacy underlying the Soviet socio-political system was formulated as supranational.

The same idea stemmed from the first political manifesto of the new government, The Decree on Peace. Researchers have long noted its obvious similarity with The Fourteen Points, which U.S. President Woodrow Wilson came up with a few months later (Belousov, 2018). The conclusion of a universal and just peace agreement without annexations and indemnities, the right of nations to self-determination, the rejection of secret diplomacy-all this implied promotion of a new supranational and supra-governmental imperative of political development for the whole world.

What the Bolsheviks set out to create can hardly be called a classical modern state, where public power and civil society coexist in parallel and have complex relations with each other. In the Soviet Union the state-society relations clearly did not fit into this framework, and their specificity can be explained in terms of totalitarianism or traditionalist paternalism (both approaches can be found in literature; see, for example, Iurchak, 2014; Kondratyeva, 2006), but one factor remains unquestionable-the principle of a united political entity cemented by a certain set of values or ideology.

What threatened this unity? The Bolsheviks confronted a key problem inherited from the Romanov Empire (Miller, 2006, p. 203219). It was their conviction that the stability of their political project would not be secured if the nationalities question remained unresolved. Its settlement would lift the interethnic contradictions. However, World War I showed that nationalism itself was an extremely dangerous 
mobilizing ideology, for it was capable of forging supra-class unity in the struggle for national goals. Nationalism was a no less dangerous competitor of Soviet Communism than Woodrow Wilson's liberalism. Following the end of the Civil War some Bolshevik leaders called for declaring nationalism (in any of its forms) an enemy and for launching an uncompromising fight against it.

Lenin, and later Stalin, opted for a different solution: if Soviet government met nationalist demands, it would be able to split the supra-class unity of nationalist movements and thereby create conditions for the deepening of class contradictions and providing fertile soil for Communist ideology (Stalin, 1947, pp.33-36). This tactics had another important advantage: it presented the new Soviet political project as an alternative to the Russian Empire as a "prison of peoples." It also had an important propaganda effect as it helped secure support from the working-class masses around the world. It was believed that all peoples will go through the stage of free national development anyway; this will go in parallel with socio-political emancipation, creating solid ground for genuine internationalism.

Another fundamental idea of the Bolsheviks' conception stemmed from a very specific nature of ethnic relations in the Russian Empire. Lenin distinguished between the nationalism of the oppressing nation and the nationalism of the oppressed nation. The former was understood in most cases as the so-called "Great Russian chauvinism," which was associated with the political and economic exploitation of the periphery and, as such, was to be eradicated. At the same time, the nationalism of minorities was to be supported. In addition to the implementation of the ideological imperative, this created a major competitive edge on the international scene. By encouraging local nationalisms in various ways, including political isolation of respective territories within the Soviet state, the Bolsheviks created attractive centers of national consolidation for nationalities living beyond the Soviet Union (primarily for Ukrainians and Belarusians).

The primary objective was depoliticization of local nationalisms by satisfying a significant part of their demands, as a rule, at the expense of the Russian political core. The policy of "positive discrimination" 
was brought to its logical end with the creation of ethnic political entities in the former imperial periphery and the implementation of the indigenization policies there. This process was accompanied by the creation (sometimes, practically from scratch) of national elites, national cultures and languages, and by balancing out the economic development of the periphery and the core through redistribution of resources (Borisyonok, 2006). This model implied that the state-forming people, the Russians, were expected to suppress their ethnic interests.

The so-called "affirmative action empire" (Martin, 2001) that emerged in Eurasia was a unique political entity. It was different not only from the Romanov Empire, but also from all other empires of modern times. It was a highly modernized empire that devised a very special response to the challenge of nationalism, but at the same time retained some traditional features. The problem of the imperial limes, known since the Roman Empire, faced the Russian tsars starting as far back as the 16th century. In the 20th century, it was inherited by the Soviet Union. The border issue played a crucial role in Soviet politics and ideology. The Soviet elites were obsessed with the task of keeping the borders intact. The most important way of protecting them was expansion and creation of new security belts. However, for the Soviet Union the borders were not only a line of defense from external influences, but also a field for interaction with the outside world, as well as a peculiar showcase of the Communist system (Diullen, 2019, pp.95215). It was only natural that the image of the border guard became one of the most characteristic Soviet propaganda symbols.

Of course, this model was not static. It kept evolving throughout all 70 years of Soviet history. In the second half of the 20th century it was supplemented by a rather loose concept of "the Soviet people as a new historical entity." The nationalities problems were considered nonexistent and the ideologies and movements that tried to articulate these problems were fiercely suppressed. Ill-considered and erratic decisions made to implement the policy of indigenization by no means benefited the "affirmative action empire." The slogan of self-determination of nations that absolutized its last part "up to secession" played an especially harmful role. 
All these experiments provided no answer to the main question: How to maintain the imperial order and carry out invariably destabilizing modernization at the same time (Lieven, 2002)? The Soviet empire could not but modernize itself. However, this implied qualitative changes in the relationship between the core and the periphery. The ability to maintain growing living standards amid the general rise in the level of education and culture was an important factor for the legitimacy of power in the modern world. The Soviet elites failed to respond to this challenge for a number of reasons, including the ongoing competition with the Western countries for power and influence in the world. Lacking sufficient flexibility, they relied on ideological palliatives, which disagreed with reality, the further the more. These policies ultimately caused the demise of the Soviet Empire in 1991.

\section{THE THIRD REICH}

The Soviet imperial model was an attempt to integrate a large variety of nationalities' lifestyles on the vast expanses of northern Eurasia. German Nazism proposed an opposite approach. Whereas the Bolsheviks' key imperative was the equality of nationalities and for the sake of its implementation they did not shy at positive discrimination of the state-forming national core (Russians), the founders of the Third Reich built a full-fledged hierarchy of nations, where the relationship among them was governed by the idea of innate inequality, which, they postulated, was a law of nature. The Bolsheviks believed that class struggle, having reached its logical end and established the reign of universal equality, would naturally remove contradictions among ethnicities and nationalities, and they would merge into a single whole. The Nazis proceeded from a different assumption: the restoration of the natural, nature-given dominance of a stronger nation over weaker ones, including the extermination of those which have not found a place for themselves in this hierarchy, will bring the end of history.

The new German state they created was conceived as eternal (the Thousand-Year Reich concept was proposed by Adolf Hitler himself 
in 1934) and consolidated by the common idea of the unity of all Germans (at the first stage) and racial unification of the conquered space (at the final stage). The first stage was of exceptional importance. What Hitler called "disrupted racial integrity" deprived the Reich of world domination. Therefore, he believed: "If the German people in its historical development had possessed that herd unity which other peoples have enjoyed, the German Reich today would doubtless be mistress of the globe" (Fest, 2009, p.352). Between the Meuse and Memel there lay a "space without people" which needed a master. Only after that the people will realize itself as an entity and be ready to fulfill its global mission. In private conversations, Hitler kept saying that "the pressing domestic mission of the National Socialist Party was to establish a nation in the empty space between the Meuse and the Memel. For what we see there today are Marxist human herds, but no longer a German nation" (Rauschning, 1940, cited by U.S. edition, p.34).

Already at this stage, the strategy of "establishing the nation" implied the elimination of "alien races." The "Aryan nucleus" began mingling with the subject people, "subhumans," and this, according to the author of Mein Kampf, became the most important prerequisite for the decline of both Germany and Europe as a whole. AntiSemitism was the basis of Nazi ideology, but for Hitler its role was also instrumental. As he once noted, if there were no Jew left, "we should have then to invent him. It is essential to have a tangible enemy, not merely an abstract one" (Rauschning, 1940, cited by U.S. edition, p.146). Launched under the slogan of purifying the "Aryan nucleus," the struggle against "bloodthirsty and avaricious Jewish tyrants of nations" was to be completed on a global scale. "Then order would once again arise out of chaos, unity would be achieved, masters and slaves would hold their proper places, and the wisely led 'nucleus peoples of the world' would respect one another and live in peace, since the root of the world's ills would at last have been eliminated" (Fest, 1974, p.247).

What Hitler was determined to build was markedly different from the Kaiser Empire. A simple return to the 1914 situation was out of the question. The borders of the Second Reich, according to Hitler, had been set randomly and looked illogical and disadvantageous for 
geographical and military reasons. The victory over France, of course, was the first step towards implementing his plans, but nothing more than that. He had no intention to confine himself to correcting the borders, which, in his opinion, did not matter at all. Any law relies on power, and if the people have the power to take this or that land, it must do so. Hitler tried to create a new space for a new people. His plans were very far from Malthusian ideas. Germany needed living space not to restore historical justice or solve the problem of overpopulation. The idea of restoring the peasant class in the face of an advancing industrial civilization, which was dear to some conservatives, was also irrelevant. Large territories were to be conquered for the sole purpose of obtaining a base for conquering the world.

At the dawn of his political career, Hitler saw Germany as a maritime colonial power that would crush the power of Great Britain. To achieve this goal, he did not even exclude an alliance with Russia, provided it had been "restored to health" and freed from the "JewishBolshevik yoke" (Fest, 1974, p.250). However, by the mid-1920s, he had revised his views and formulated a program for conquering a living space in the East, which he described in Mein Kampf. It was a largescale imperial project. Hitler believed that the golden age of maritime empires was gone. Progress in science and engineering, which made it possible to build railways and highways for a new type of vehicles, depreciated the role of shipping routes as the most convenient link between the core of the empire and its periphery. Therefore, the next world empire would be a continental power, a kind of a single territorial complex connected by highways and protected by a mighty land force (Trevor-Roper, 2000, XXII).

On this path, Germany was doomed to clash with Russia-the only empire that could block the way of the new German Reich. Here Hitler approached the same problem that troubled the political elite of the Kaiser Empire on the eve of 1914 (Lieven, 2015). He intended to finalize what Wilhelm II had failed to accomplish. After defeating Russia Germany would have its own "India" in the East: an inexhaustible source of material and human resources. The Slavic "subhumans" were to be partly exterminated and partly enslaved. This was Hitler's vision 
of the "dawn of the Thousand-Year Reich," the moment of the German nation's historical triumph. It was the Germans that Providence had chosen for a special mission, so the fate of other Europeans was to join them. This is how the idea of a "new order" for Europe took shape.

According to the Nazis, successful implementation of their project was the key to the survival of the Old World. They contrasted their project to both Western (liberal) and Soviet (Communist) ones. The Nazis regarded both as manifestations of the same phenomenon. "From the Nazi point of view," says Pierre Manent, "Communism was not an overthrow of capitalism, but its highest stage. Communism for them was the final, crushing, irreversible victory of 'the most despicable man' that Nietzsche's Zarathustra talked about, 'the last man,' entirely focused on his needs and ways to satisfy them, a man who is completely 'economic"' (Manent, 2004, p.262).

This made Hitler's project global in the full sense of the word. One hundred million Germans would subjugate Europe to become a collective world hegemon and defeat the United States of America in the struggle for this status. Back in the 1920s, Hitler saw the economic and political rise of the U.S. as a challenge to all European countries. If their leaders fail to wrest the populations of their countries from "political folly," then the "looming global hegemony of the North American continent" will downgrade everyone to the position of "Switzerland and Holland" (Weinberg, 1961, pp.127-128). The only country that could oppose the United States would be one that "understands how the essence of domestic life and the meaning of foreign policy can increase the racial value of its people and endow it with a statehood that is most suitable for this purpose" (Tooze, 2019a, pp.36 -38).

Hitler saw his task in preparing Germany for this mission. Great Britain was to become an ally of the Third Reich in the struggle against American hegemony. Two Germanic-speaking peoples would join forces under the aegis of the Thousand-Year Reich. There was no alternative to its worldwide triumph. As Hitler himself repeatedly said, Germany would either rule the world or perish. He remained committed to this belief until the last days of his life, when, realizing the inevitability of defeat, he said to Albert Speer: "If the war is to be 
lost, the nation also will perish. There is no need to consider the basis even of the most primitive existence. On the contrary, it is better to destroy it, and to destroy it ourselves. The future belongs solely to the stronger Eastern nation" (Trevor-Roper, 2000, p. XXXIV).

The destructive potential of the Nazi project was enormous. The Third Reich was only crushed by military means, and its political and ideological framework was consistently dismantled in accordance with a policy of creating a "new Germany." On the ruins of the Third Reich, a German nation-state emerged with a powerful civil society that tightly controls the authorities. A common European space has become the field for its progress. A united Europe's development far and wide corresponded to the internal needs of German society and, at the same time, was considered beneficial from the standpoint of preserving the European world. The rejection of the Nazi experiment furnished the basis for consolidation of post-war German society and the emergence of a new European identity.

\section{THE AMERICAN "EMPIRE BY INVITATION"}

World War II drew a line under the centuries-old global domination of European colonial powers. Two superpowers-Soviet and Americanassumed responsibility for the world's future. The question about the nature of American statehood keeps fueling intense discussions among historians and political scientists. A country that has put so much effort into the struggle against the "evil empire" finds it difficult today to acknowledge that by many criteria it is an empire itself. At the turn of the 20th-21st centuries the neoconservatives tried to revise the current discourse by stating that the country was not only the sole superpower, but also an empire based on democratic values. As Niall Ferguson notes, "the United States has always been, functionally if not self-consciously, an empire" (Ferguson, 2009, p. 39). In his opinion, the Americans should recognize the imperial character of their modern power and learn from the achievements and mistakes of empires of the past. There are those who disagree with such a vision (for example, Robert Kagan (Kagan, 2003)), but in fact they talk about the same things using a different vocabulary. 
Messianism has been inherent in the American political culture since the country gained independence. Protestant communities that had resettled to North America were certain they were the chosen ones, destined to accomplish a special mission of building a shining city upon a hill. All founding fathers, starting with George Washington, shared this idea, but until a certain moment it did not entail the imperative of expansion. It was believed it would be enough for the Americans to serve as an example of perfect democracy. The situation changed in the 19th century with the emergence of strong discourse about an inseparable link between democratic messianism and expansion. According to V. Sogrin, the "imperial gene was already in there" (Sogrin, 2013, p.63).

Tentatively speaking, there have been three empires in American history. One took root on the vast expanses of the North American continent. In 1845, during the war with Mexico, the most important manifesto of the American empire was formulated. It was called Manifest Destiny. According to one of its authors, U.S. rights to continental dominance stemmed from the fact that Americans "are predetermined by fate to extend their dominion to the entire continent, which was granted to us by Providence to fulfill the Great Mission entrusted to us: establish freedom and federative self-government" (Sogrin, 2013, p.63). American expansion gradually spread to the entire Western hemisphere. In the 20th century, there emerged another incentive for U.S. messianism: the United States turned itself into the world's number one economy.

Wilson's Fourteen Points were the manifesto of the second American empire, as well as the American empire as such. This is how Henry Kissinger described their significance: "America refused the role of being just another state among many pursuing their national interests. Implicit in Wilson's doctrine was a rejection of the sort of moral equivalence that would place the United States on the same moral grounds as other states. The American vocation, according to Woodrow Wilson, the only valid purpose for America's entry into the war was to remake the world in its own image" (Kissinger, 2001, p.243). 
The long-held doctrine of isolationism by no means contradicted the idea of global dominance: American expansion was not so much political as economic and cultural. As F. Voitolovsky notes, American isolationism has a special nature: it "involves not only the protection of one's own territory and one's own citizens, but also the creation of an international environment, of a world that will be safe for the United States. This aspiration encourages active intervention in the affairs of other regions of the world. In other words, isolationism encourages the United States to pursue an aggressive foreign policy" (Voitolovsky, 2017, p.163). Aware of its role of an "international policeman," America turned increasingly active to intervene in European affairs. Woodrow Wilson in 1918 brought American troops to Europe for the first time. Twenty years later, Roosevelt painstakingly explained to the isolationist lobby in Congress the real need for U.S. involvement in world affairs.

Finally, the United States became a global empire after World War II. At that time no other Western country was capable of taking on the function of maintaining order and restoring European nations. Washington's dominance might have had only one alternativeMoscow's dominance-but this was unacceptable to a majority of the Western elite for ideological and political reasons. The "come, set things right and leave" model, tested in 1918-1919, no longer matched the new realities. In order "to keep the Russians out, the Americans in, and the Germans down" (a formula attributed to NATO's first Secretary General Hastings Ismay), America was to be brought to Europe. But that did not seem enough. President Harry Truman believed that Communism spelled chaos. Consequently, the United States should be present at any place where the threat of Soviet expansion arises. In this way protection of the Western order turned into an excuse for global expansion. This is how the third American empire, the one that exists today, was brought into being.

In the second half of the 20th century the United States confidently acted as an "empire by invitation" (Lundestad, 1986, pp.263-277). It won the peoples' sympathies, relying on an attractive model of social and economic development. The empire by invitation took control of a significant part of the world. It was a new type of domination. While 
the empires of the past, as a rule, sought to formally incorporate a certain territory, the 20th-century empires confined themselves to indirect control, if possible, without resorting to force. The very fact of military intervention with the aim of maintaining imperial hegemony testified to its weakness. Under the umbrella of global American power, and often under the pressure of a senior ally, the old European colonial powers relatively painlessly dismantled their empires and embarked on the path of building full-fledged nation-states. Inoculated with American democracy, the European states formed stable political institutions and strong civil societies and coped, by and large, with the problems of state-building that had caused the crisis in the 1930s.

It is noteworthy that certain phenomena, similar in terms of consequences but not in form, also took place in Eastern Europe, which was in the Soviet sphere of influence. During the interwar period, nation-state building projects encountered a serious challenge of ethnic diversity of space. The revision of borders after 1945 and population exchanges solved this problem by and large. Poland, Hungary, Romania, and the Czech Republic became ethnically more homogeneous, which enabled them to start building stable sociopolitical institutions. Soviet military dominance put an end to wars for the "indigenous" territories. The only Eastern European country that retained its heterogeneous ethnic composition in the second half of the 20th century was Yugoslavia, which was not entirely inside the Soviet sphere of influence. Its socio-political structure model was unable to resolve ethnic conflicts on its own and, ultimately, perished along with the state itself. The European Union assumed responsibility for "restoring order" in this territory in the 1990s.

The American imperialness, just like its Soviet counterpart did in its day, handles the nationalities problem through the conceptualization of supranational unity. Its protagonists propose a model of political structure that neutralizes ethnic contradictions and pushes them into the background. From their point of view, America has set an example of how a variety of cultures and peoples can merge in a "melting pot" united by common values. Since the time of Woodrow Wilson, the Americans have pressed for the right of nations to self-determination. 
Empires that rely on power and dictatorship must disappear to give way to the sole fair form of domination - the rule of fair values, which ultimately leads to convergence. One way or another, this imperative eventually turned into a form of military-political hegemony. The adoption of a socio-political model built by American templates was associated with economic growth and an overall improvement in living standards. Indeed, it was this circumstance that made the "empire by invitation" particularly attractive. In reality, though, the economy was used as an instrument of expansion. Keeping Europe inside the sphere of American influence was the direct aim of the Marshall Plan launched in 1947. A similar mechanism worked in Japan as well.

Slavoj Žižek writes about the nature of the American empire: “The problem with today's USA is not that it is a new global Empire, but that it is not; in other words, that, while pretending to be, it continues to act as a nation-state, ruthlessly pursuing its own interests. It is as if the guiding principle of recent U.S. politics is a weird rehearsal of the well-known ecologists' motto 'act globally, think locally"' (Žižek, 2005, pp.19-20). The American establishment is indeed inclined to believe that U.S. national interests are a common denominator of the collective good on a global scale. "An international order that reflects our values is the best guarantee of our enduring national interest, and America continues to have a unique opportunity to shape this outcome," Condoleezza Rice said in 2008 (Rice, 2008, p.26). George W. Bush expressed the same idea in his 2005 inaugural address: "The survival of liberty in our land increasingly depends on the success of liberty in other lands. The best hope for peace in our world is the expansion of freedom in all the world. America's vital interests and our deepest beliefs are now one" (Bush, 2005). American values, American national interest and creation of an ideal world order are different names for the same phenomenon, and the "expansion of freedom" coincides with the expansion of U.S. political influence.

\section{THE EUROPEAN UNION AS AN EMPIRE}

However, maintaining order around the world, apparently, is beyond America's power. Over the past decade, it has become increasingly 
apparent that its resources are not unlimited, while the world is too complex to be governed relying on a single set of values. The Old World, which during the Cold War developed within the framework of the global American empire, took an independent development course in the format of European integration. Its nature remains in the focus of ongoing debates. In 2007, José Manuel Barroso, then President of the European Commission, compared the European Union with an empire, but made a reservation that it was a "non-imperial empire." The EU, he claimed, is based on fundamentally different values than the empires of the past, its expansion does not permit violence (in contrast to U.S. policies). It may be more correct to call the European Union a "soft" empire-while relying on non-violent methods of expansion an empire does not cease to be an empire.

It is not accidental that the European integration project unfolded on the territory that had once been the core of Charlemagne's empire. Researchers have long noticed that if it makes sense at all to compare the EU with empires of the past, then the Frankish Empire and the Holy Roman Empire of the German Nation can serve as the closest analogues (Engelmann, 1962, pp.297-301). In both cases, the basis of political integration was axiological: Christianity and "faith in the continuity of the empire in finem saeculi" (Kantorovich, 2005, p.267) in the case of the Holy Roman Empire, and European values in the case of the EU. Both the medieval empire and the European Union of the 20th-21st centuries are sufficiently disintegrated political entities, with their constituent nations retaining a large share of sovereignty. The absence of an unequivocal political core is another feature they share.

The main tasks of European integration are quite close to imperial goal setting. The main goals of the EU's founding fathers were bringing order into the lives of countries and peoples and devising common rules that can stop chaos and fierce competition which causes destructive wars. The idea of order, of ousting chaos beyond the clearly defined universe is an important part of the imperial project, and it was fully taken into account when planning European integration. The European project has always retained a major value 
component, but the initial task was to achieve internal stabilization within the space it encompassed. The European institutions were to serve just as an example (Romanova, 2013), but soon an expansion motive emerged.

The collapse of the Soviet empire vacated a vast foreground on the EU's eastern borders. The EU's enlargement into this territory served as a mechanism for restoring order in a situation of drastic change in the surrounding environment. Border countries got the chance to join the European Union in exchange for loyalty and adherence to certain general rules. It was a way of maintaining a balance similar to retaining Soviet military dominance in Eastern European countries, but much more attractive to them. The hotbeds of interethnic conflicts were extinguished, and some clashes were generally nipped in the bud. In addition, the expansion of European institutions played an important symbolic role, thus confirming the idea that the European integration model was universal. This factor acquired special significance after the first decade of the 21st century, when "internal integration" began to exhaust its potential (Zielonka, 2006).

The EU's continuous enlargement furnished the foundation for the European project's self-identification, largely becoming an end in itself. The exhaustion of its economic potential and the EU's spread beyond the natural geographical limits of European culture sparked concerns but did not lead to a revision of the basic guidelines. Various palliatives such as the Eastern Partnership project were invented, which created the illusion the expansion was going on. The European Neighborhood Policy invited the bordering countries to join the EU on everything-but-institutions conditions. The states participating in it became part of the European periphery in exchange for political loyalty.

Today, the "soft empire" faces several existential challenges. The eastward expansion, which began in the 1990s, has encountered a number of obstacles that the EU is unable to overcome at the moment. The very possibility of suspending the expansion frightens European elites, while the reverse process of secession from the European Union, with the Brexit showing that such prospects do exist, poses a fateful 
challenge. The impossibility of further outward expansion might be offset by the resumption of "internal integration," however, there remain certain questions that have no clear answers. The potential for deepening is objectively limited by the association's loose political structure (Krastev, 2018).

The problem of the core and the periphery in the EU is not emphasized at the official level for the reasons of political correctness, but it is objectively on the agenda. In fact, they do exist, and the core, with Germany ever more often positioning itself in this capacity, seeks to consolidate its status at the expense of the periphery. This process is objective: the instrument of consensus in working out common decisions is about to exhaust itself and the question of converting economic and cultural hegemony into the political one is increasingly present on the agenda. However, this has not yet happened, and the imperial core in the EU has not been fully formed. Moreover, attempts to formally fix it in an appropriate legal framework are stalled. This is the main obstacle that the European project will be unable to get round on the way towards forming an empire.

Another issue, which is important for the future of the European project and which remains unresolved is the emancipation from U.S. influence and transformation of the EU into a global center of power. The "shy" empire is doomed to lose its status. This means the Europeans will have to re-master some of their long-lost skills: to formulate and implement a coherent foreign and defense policy (Tevdoï-Burmuli, 2019, pp.97-98). The prospects that these tasks will be implemented by the EU leadership are not obvious. But it is fairly clear that a failure of the European project will lead to destabilization of the entire Eastern European periphery. Already now, the desire of some countries, such as Ukraine, to solve the problems of their state-building project using the model once employed by Eastern European countries looks futile as the European institutions' expansion resource is close to zero. Their collapse will certainly entail still more harmful consequences and may once again turn Eastern Europe into a field of clashes between powerful external forces fighting to secure their interests. 


\section{$* * *$}

In the 20th century the system of imperial domination allowed the nation-state to gain strength in different parts of the world. Reformatting the system of international relations at the beginning of the 21st century requires that nation-states rethink their place in world affairs. This process develops unevenly and is accompanied by dangerous breakdowns. The list of the so-called failed states is growing. In a situation where there is no universally recognized order, competition among leading world players is going into high gear. However, there are visible contours of a model that may help overcome the current crisis. As V. Lapkin notes, "such an empirically reliable, but theoretically unforeseen solution is the emergence-'above' the common and universal nation-state system in the modern world-of some imperial forms of political integration based on latent cultural and civilizational resources that have survived the previous expansion of Western universalism" (Lapkin, 2018, p.51). The near future will show what these imperial structures will be like in the context of modern development, what they will inherit from the past, and to what extent they may become political know-how.

\section{References}

Belousov, L., 2018. Revolyutsionnyie sobytiya v Rossii v vospriiatii praviashchikh krugov stran Yevropy i Ameriki (1917-1918) [Revolutionary Events in Russia in the Perception of the Ruling Circles of the Countries of Europe and America (1917-1918). In: I. Tuchkov (ed). Stoletiie Revoliutsii 1917 goda v Rossii. [A Centenary of the 1917 Revolution in Russia]. Collection of Articles, Vol. 1. Moscow.

Borisyonok, I., 2006. Fenomen sovetskoi ukrainizatsii v 1920-1930-ye gody [The Phenomenon of Soviet Ukrainization in the 1920s-1930s]. Moscow: Evropa.

Bourdieu, P., 2012. Sur l'Etat. Cours au Collège de France (1989-1992) [On the State. Courses at Collège de France (1989-1992)]. Paris.

Bush, G.W., 2005. Inaugural Address [online]. Available at: https://www.nytimes. com/2005/01/20/politics/inaugural-address-by-george-w-bush.html [Accessed on 29 January 2020].

Colley, L., 1992. Britons. Forging a Nation. London: Pimlico. 
D'Agostino, A., 2012. The Rise of Global Powers: International Politics in the Era of the World Wars. Cambridge: Cambridge University Press.

Diullen, S., 2019. Uplotnenie granits. K istokam sovetskoi politiki. 1920-1940e [Sealing Boundaries. Back to the Origins of Soviet Politics. The 1920s-1940s]. Moscow: Novoye Literaturnoye Obozrenie.

Eisenstadt, S.N., 1963. The Political Systems of Empires. New York: The Free Press of Glencoe.

Engelmann, H.O., 1962. The European Empire: From Charlemagne to the Common Market. Social Forces, Vol. 40, No. 4.

Ferguson, N., 2009. American Democracy: The Perils of Imperialism? In: R. Faulkner and S.M. Shell (eds.). America at Risk: Threats to Liberal SelfGovernment in an Age of Uncertainty. Ann Arbor: University of Michigan Press.

Fest, I. C, 1974. Hitler. Translated from German by Richard and Clara Winston. Harcourt, Inc.

Hobson, J., 1902. Imperialism: A Study. New York.

Hobsbawm, E.J., 1987. The Age of Empire: 1875-1914. London: Weidenfeld and Nicolson.

Iurchak, A., 2014. Eto bylo navsegda, poka ne konchilos' [It Was Forever until It Was No More]. Moscow: Novoye Literaturnoye Obozrenie.

Kagan, R., 2003. On Paradise and Power: America and Europe in the New World Order. New York: Knopf.

Kantorovich, E., 2005. Dva tela korol'ya. Issledovanie po srednevekovoi politicheskoi teologii [The King's Two Bodies: A Study of Medieval Political Theology]. Moscow: Gaidar Institute.

Kissinger, H., 2001. Does America Need a Foreign Policy? Toward a Diplomacy for the 21st Century. New York: Simon and Schuster Paperbacks.

Kondratyeva, T., 2006. Kormit' i pravit': O vlasti v Rossii XVI-XX vv. [To Feed and Rule. On the Power in Russia of the 16th-20th Centuries]. Moscow: ROSSPEN.

Krastev, I., 2018. Posle Evropy [After Europe]. Moscow: Delo Publishing House.

Lapkin, V., 2018. O natsional'nom vs imperskom obustroïstve sovremennogo miroporiadka [About National vs Imperial Arrangement of the Modern World Order]. Polis. Politicheskiye issledovaniya, No. 4. 
Lenin, V., 1969a. Gosudarstvo i revolutsiia [State and Revolution]. Collection of Works. Vol. 33. Moscow: Izdatel'stvo politicheskoï literatury.

Lenin, V., 1969b. Imperializm kak vysshaya stadiya kapitalizma [Imperialism as the Highest Stage of Capitalism]. Collection of Works, Vol. 27. Moscow: Izdatel'stvo Politicheskoi Literatury.

Lieven, D., 2002. The Russian Empire and Its Rivals. Yale University Press.

Lieven, D., 2015 Towards the Flame: Empire, War and the End of Tsarist Russia. Allen Lane.

Lundestad, G., 1986. Empire by Invitation? The United States and Western Europe, 1945-1952. Journal of Peace Research, Vol. 23, No. 3.

Manent, P., 2004. Obshchedostupny kurs politicheskoi filosofii [A Public Course in Political Philosophy]. Moscow.

Mann, M., 1986. The Sources of Social Power. Vol.1. A History of Power from the Beginning to A.D. 1760. Cambridge: Cambridge University Press.

Martin, T., 2001. An Affirmative Action Empire: Nations and Nationalism in the Soviet Union, 1923-1939. Ithaca: Cornell University Press.

Miller, A., 2006. Imperiia Romanovykh i natsionalizm: Esse po metodologii istoricheskogo issledovaniia [The Romanov Empire and Nationalism. An Essay on the Methods of Historical Studies]. Moscow: Novoye literaturnoye obozrenie. Miller, A., 2016. Natsiya, ili mogushchestvo mifa. [The Nation, or The Power of Myth]. Saint-Petersburg: The European University in St. Petersburg

Rauschning, H., 1940. Gespräche mit Hitler [Conversations with Hitler]. Zürich: Europa Verlag. (U.S. edition: The Voice of Destruction. New York: G.P. Putnam's Sons)

Rice, C., 2008. Rethinking the National Interest. American Realism for a New World. Foreign Affairs, Vol. 87, No. 4.

Romanova, T., 2013. Imperiya norm [The Empire of Norms]. Rossiya v globalnoi politike, No.1 January-February [online]. Available at: < https://globalaffairs.ru/ number/Imperiya-norm-15876> [Accessed 29 January 2020].

Sogrin, V., 2013. Rozhdeniie amerikanskoï imperii: 1898-1918. Prichiny, tseli, metody [The Birth of the American Empire. Causes, Aims, Methods]. Novaya i noveyshaia istoriya, No 3.

Stalin, I., 1947. Sochineniia [Collection of Works]. Vol. 4. Moscow. 
Strayer, J.R., 1970. On the Medieval Origins of the Modern State. Princeton: Princeton University Press.

Tevdoï-Burmuli, A., 2019. Yevropeyskiï soiuz kak imperskiï konstrukt: k voprosu o primenimosti ponyatiia [The European Union as an Imperial Construct: On the Applicability of the Notion]. Mezhdunarodnyie protsessy, Vol. 17, No. 2.

Tilli, Ch., 2009. Prinuzhdeniye, kapital i yevropeyskiye gosudarstva. 1990-1992 gg. [Coercion, Capital, and European States, 990-1990]. Moscow: Territoriya Budushchego.

Tooze, A., 2019a. Tsena razrusheniya. Sozdaniye i gibel' natsistskoï ekonomiki [The Cost of Destruction: The Creation and the Breakdown of the Nazi Economy]. Moscow: Gaidar Institute.

Tooze, A., 2019b. Vsemirny potop. Velikaya voina i pereustroistvo mirovogo poryadka, 1916-1931 gody [The Deluge: The Great War and the Remaking of the Global Order, 1916-1931]. Moscow: Gaidar Institute.

Trevor-Roper, H.R., 2000. The Mind of Adolf Hitler, in Hitler's Table Talk. 19411944. His Private Conversations. New York: Enigma Books.

Voitolovsky, F., 2017. Opredelenie strategicheskikh tselei - eto sfera ideologii [Setting Strategic Goals Is the Sphere of Ideology]. Mezhdunarodnyie protsessy, Vol. 15, No 1.

Weber, E., 1976. Peasants into Frenchmen. The Modernization of Rural France, 1870-1914. Stanford: Stanford University Press.

Weinberg, G. (ed.), 1961. Hitlers Zweites Buch: Ein Dokumentausdem Jahr 1928 [Hitler's Second Book: A Document from 1928]. Stuttgart: Deutsche VerlagsAnstalt.

Zielonka J., 2006. Europe as Empire: The Nature of the Enlarged European Union. Oxford: Oxford University Press.

Žižek S., 2005. Iraq: The Borrowed Kettle. London: Verso. 